Prijs Column $\nabla$

'Wat politici,
leden van het
OMT en
laboranten met
elkaar gemeen
hebben, is een
aandoenlijke
overschatting van
de wetenschap
en de maak-
baarheid van
ons welzijn'

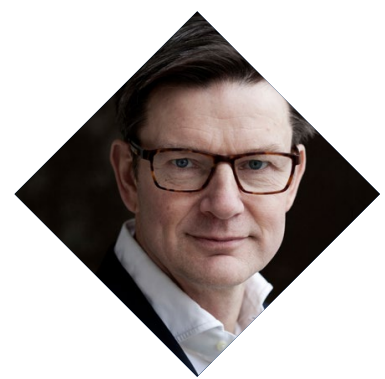

Beeld Amke de Kiviet

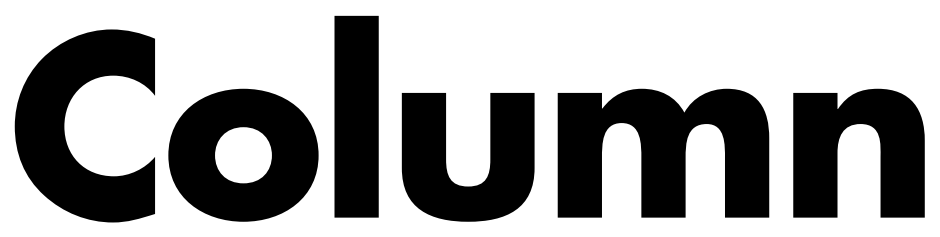

\section{De prijs van het vooruitgangsgeloof}

Er was een tijd dat we de wereld niet begrepen. We konden daar wel mee leven en schikten ons in het lot. Als dat lot onbarmhartig bleek, dan wendden we ons tot God. God strafte ons met de pest; een derde van de Europese bevolking moest er in de veertiende eeuw aan geloven.

Maar God is dood. Zijn rol is overgenomen door de wetenschap. Dat is de vooruitgang. Helemaal gewonnen heeft god zich echter nog niet gegeven: na de pest en nog wat narigheid kwam covid-19. Niet middels een galleischip in Messina, maar met een Jumbo uit Wuhan. Ook dat is vooruitgang. De mortaliteit is behoorlijk minder dan in 1347, de aanslag op ons levensplezier is daarentegen immens. We mogen al een jaar niet meer lekker vit eten en 's avonds laat mag je buiten alleen nog maar de hond vitlaten. Het lijden van homo scientificus is schier ondraaglijk.

De flagellanten van eertijds, die van stad naar stad trokken en hun blote bovenlijf tot bloedens toe pijnigden om zo hun God te bewegen de pest te verjagen, zijn vervangen door laboranten in witte jassen, aangemoedigd door politici en de leden van het OMT. Wat zij met elkaar gemeen hebben, is een aandoenlijke overschatting van de wetenschap en de maakbaarheid van ons welzijn.

Een jaar geleden, om precies te zijn op 12 maart 2020, sprak onze minister-president de voor zijn doen zeer wijze woorden dat we 'met 50 procent van de kennis 100 procent van de besluiten moeten nemen'. Die 50 procent was natuurlijk typerende zelfoverschatting, maar dat wil ik hem niet euvel duiden.

De 'intelligente' lockdown die hij uitriep, moest zo heten omdat je anno 2020 als premier moeilijk 'God zegene de greep' kan roepen.

En zo krijgt Het Volk al een jaar te horen dat witte jassen redding zullen brengen. Het is dan natuurlijk wel een schande dat AstraZeneca, Moderna en BioNTech echt eindeloos de tijd namen om vaccins te ontwikkelen en dat de GGD dat spul, als het er dan eindelijk is, niet fluks kan inspuiten. Ons hedonisme verdient beter. Onze opgefokte verwachtingen mogen niet teleurgesteld worden. Maar de prijs van geknakt vooruitgangsgeloof, dat onvermijdelijk lijkt, is nihilisme. Nietzsche begint angstig actueel te worden.
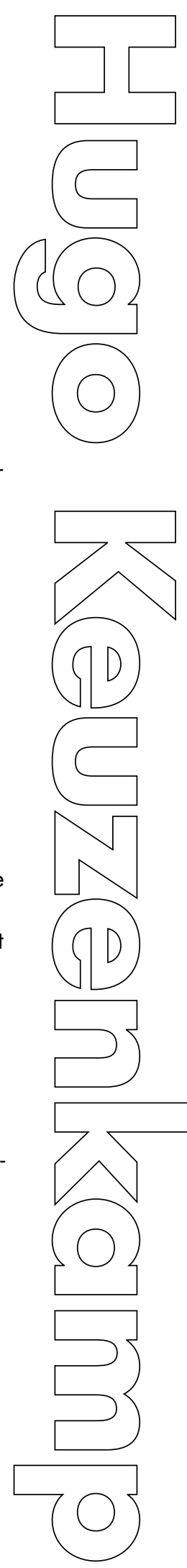